\section{Structural and Functional Properties of Neocartilage Construct Engineered in Poly (Lactic-co- Glycolic Acid) (PLGA) based Scaffolds}

By: Tahir, AHMA (Tahir, Aisyah Hanani Md Ali) ${ }^{[1]}$; Amin, MAIM (Amin, Muhammad Azri Ifwat Mohamed) ${ }^{[1]}$; Azhim, A (Azhim, Azran) $)^{[1]}$; Sha'ban, M (Sha'ban, Munirah) ${ }^{[2]}$

\section{INTERNATIONAL JOURNAL OF INTEGRATED ENGINEERING}

Volume: 11 Issue: 3 Pages: 109-118 Special Issue: SI

Published: 2019

Document Type: Article

\section{Abstract}

The study aims to assess the structural and functional properties of in vitro three-dimensional (3D) PLGA-based hybrid scaffolds seeded with chondrocytes, particularly in terms of the production of specific cartilaginous extracellular matrix (ECM). The PLGA scaffolds were incorporated with atelocollagen and/or fresh fibrin and assigned to four groups; PLGA only as control, PLGA-fibrin (PF), PLGA-atelocollagen (PA) and PLGA-atelocollagenfibrin (PAF). The resulting PLGA hybrid scaffolds were characterized based on gross appearance, attenuated total reflectance-Fourier transform infrared (ATR-FTIR) spectroscopy analysis, porosity and swelling tests as well as cytocompatibility analysis using cell proliferation (MTT) assay. All scaffolds seeded with cells were cultured for three weeks in vitro. Macroscopic changes were recorded using photographs. Microscopic evaluation of 'cells-scaffolds' construct was done using Haematoxylin and Eosin (H\&E), Safranin O, Alcian Blue, Toluidine Blue and scanning electron microscopy (SEM). The production of cartilage specific ECM was measured using sulphated glycosaminoglycan ( $\mathrm{SGAG}$ ) assay. Based on physical characterizations, PLGA-based hybrid scaffolds have been successfully manufactured and showed no cytocompatibility issues. The PAF exhibited cartilaginous tissue morphology better than other scaffold groups, grossly and microscopically. On SEM, the presence of branching fibers that produce a web-like network on the surface of PLGAbased hybrid scaffolds indicated ECM secretion. This is supported by the manifestation of glycosaminoglycan and as well as proteoglycan through histology and SGAG assay. This present study indicated that PLGA-based hybrid scaffolds promote formation of neocartilage in vitro.

\section{Keywords}

Author Keywords: tissue engineering; neocartilage; extracellular matrix; bioscaffold; PLGA; atelocollagen; fibrin

KeyWords Plus: MESENCHYMAL STEM-CELLS; IN-VITRO DEGRADATION; ARTICULAR-CARTILAGE; HYBRID SCAFFOLD; TISSUE; ATELOCOLLAGEN; GELATIN; DESIGN; GROWTH

\section{Author Information}

Reprint Address: Sha'ban, M (reprint author)

+ Int Islamic Univ Malaysia, Kulliyyah Allied Hlth Sci, Dept Phys Rehabil Sci, Jalan Sultan Haji Ahmad Shah, Kuantan 25200, Pahang, Malaysia. Addresses:

+ [1] Int Islamic Univ Malaysia, Dept Biomed Sci, Kulliyyah Allied Hlth Sci, Jalan Sultan Haji Ahmad Shah, Kuantan 25200, Pahang, Malaysia

+ [2] Int Islamic Univ Malaysia, Kulliyyah Allied Hlth Sci, Dept Phys Rehabil Sci, Jalan Sultan Haji Ahmad Shah, Kuantan 25200, Pahang, Malaysia E-mail Addresses: munirahshaban@iium.edu.my

Funding

\begin{tabular}{|l|l|}
\hline Funding Agency & Grant Number \\
\hline $\begin{array}{l}\text { Kulliyyah of Allied Health Sciences, International Islamic University Malaysia (IIUM), Kuantan } \\
\text { Campus }\end{array}$ & \\
\hline Tissue Engineering and Regenerative Medicine Research Team, IIUM & \\
\hline Ministry of Education (MOE) & $\begin{array}{l}\text { TRGS/1/2016/UIAM/02/8/2 (TRGS16-02-002- } \\
0002)\end{array}$ \\
\hline
\end{tabular}

View funding text

Publisher

UNIV TUN HUSSEIN ONN MALAYSIA, 86400 PARIT RAJA, BATU PAHAT, JOHOR, 00000, MALAYSIA

\section{Categories / Classification}

Research Areas: Engineering

Web of Science Categories: Engineering, Multidisciplinary

\section{Citation Network}

In Web of Science Core Collection

0

Times Cited

Create Citation Alert

\section{0}

Cited References

View Related Records

Use in Web of Science

Web of Science Usage Count

0

Last 180 Days $\quad$ Since 2013

Learn more

This record is from:

Web of Science Core Collection

- Emerging Sources Citation Index

Suggest a correction

If you would like to improve the quality of the data in this record, please suggest a correction.

See more data fields 
1. Natural and synthetic biodegradable polymers: different scaffolds for cell expansion and tissue formation

By: Asti, Annalia; Gioglio, Luciana

INTERNATIONAL JOURNAL OF ARTIFICIAL ORGANS Volume: 37 Issue: 3 Pages: 187-205 Published: MAR 2014

2. Articular cartilage: Tissue design and chondrocyte-matrix interactions

Times Cited: 443

By: Buckwalter, JA; Mankin, HJ

INSTRUCTIONAL COURSE LECTURES, VOL 47 - 1998 Book Series: AMERICAN ACADEMY OF ORTHOPAEDIC SURGEONS INSTRUCTIONAL COURSE LECTURES Volume: 47 Pages:

477-486 Published: 1998

3. The influence of structural design of PLGA/collagen hybrid scaffolds in cartilage tissue engineering

Times Cited: 166

By: Dai, Wenda; Kawazoe, Naoki; Lin, Xiaoting; et al.

BIOMATERIALS Volume: 31 Issue: 8 Pages: 2141-2152 Published: MAR 2010

4. Analysis of cell growth in three-dimensional scaffolds

Times Cited: 82

By: Dunn, JCY; Chan, WY; Cristini, V; et al.

TISSUE ENGINEERING Volume: 12 Issue: 4 Pages: 705-716 Published:APR 2006

5. The Basic Science of Articular Cartilage: Structure, Composition, and Function

Times Cited: 429

By: Fox, Alice J. Sophia; Bedi, Asheesh; Rodeo, Scott A.

SPORTS HEALTH-A MULTIDISCIPLINARY APPROACH Volume: 1 Issue: 6 Pages: 461-468 Published: NOV-DEC 2009

6. Visual evidence of acidic environment within degrading poly(lactic-co-glycolic acid) (PLGA) microspheres

Times Cited: 520

By: Fu, K; Pack, DW; Klibanov, AM; et al.

PHARMACEUTICAL RESEARCH Volume: 17 Issue: 1 Pages: 100-106 Published: JAN 2000

7. Metabolic Modeling of Common Escherichia coli Strains in Human Gut Microbiome

Times Cited: 10

By: Gao, Yue-Dong; Zhao, Yuqi; Huang, Jingfei

BIOMED RESEARCH INTERNATIONAL Article Number: 694967 Published: 2014

8. An Overview of Poly(lactic-co-glycolic) Acid (PLGA)-Based Biomaterials for Bone Tissue Engineering

Times Cited: 435

By: Gentile, Piergiorgio; Chiono, Valeria; Carmagnola, Irene; et al.

INTERNATIONAL JOURNAL OF MOLECULAR SCIENCES Volume: 15 Issue: 3 Pages: 3640-3659 Published: MAR 2014

9. In Vivo Cartilage Formation Using Chondrogenic-Differentiated Human Adipose-Derived Mesenchymal Stem Cells Mixed With Fibrin Glue

Times Cited: 29 By: Jung, Sung-No; Rhie, Jong Won; Kwon, Ho; et al.

JOURNAL OF CRANIOFACIAL SURGERY Volume: 21 Issue: 2 Pages: 468-472 Published: MAR 2010

10. Title: [not available]

Times Cited: 18

Edited by: Khang, G.; Kim, M. S.; Lee, H. B.

A manual for biomaterials scaffold fabrication technology Published: 2007

Publisher: World Scientific Publishing, Hachensack, NJ

11. Influence of macroporous protein scaffolds on bone tissue engineering from bone marrow stem cells

Times Cited: 223

By: Kim, HJ; Kim, UJ; Vunjak-Novakovic, G; et al.

BIOMATERIALS Volume: 26 Issue: 21 Pages: 4442-4452 Published: JUL 2005

12. Effect of pore sizes of PLGA scaffolds on mechanical properties and cell behaviour for nucleus pulposus regeneration in vivo

Times Cited: 25

By: Kim, Hye Yun; Kim, Ha Neul; Lee, So Jin; et al.

JOURNAL OF TISSUE ENGINEERING AND REGENERATIVE MEDICINE Volume: 11 Issue: 1 Pages: 44-57 Published: JAN 2017

13. Effect of pore size on ECM secretion and cell growth in gelatin scaffold for articular cartilage tissue engineering

Times Cited: 319

By: Lien, Sio-Mei; Ko, Liang-Yu; Huang, Ta-Jen

ACTA BIOMATERIALIA Volume: 5 Issue: 2 Pages: 670-679 Published: FEB 2009

14. Three-Dimensional Scaffolds for Tissue Engineering Applications: Role of Porosity and Pore Size

Times Cited: 713

By: Loh, Qiu Li; Choong, Cleo

TISSUE ENGINEERING PART B-REVIEWS Volume: 19 Issue: 6 Pages: 485-502 Published: DEC 12013

15. In vitro degradation of porous poly(L-lactic acid) foams

Times Cited: 178

By: Lu, LC; Peter, SJ; Lyman, MD; et al.

BIOMATERIALS Volume: 21 Issue: 15 Pages: 1595-1605 Published:AUG 2000

16. Fabrication and characterization of three-dimensional poly(lactic acid-co-glycolic acid), atelocollagen, and fibrin bioscaffold composite for intervertebral Times Cited: 4 disk tissue engineering application

By: Mohamad, Mohd Yusof; Amin, Muhammad Azri lfwat Mohamed; Harun, Ahmad Fahmi; et al.

JOURNAL OF BIOACTIVE AND COMPATIBLE POLYMERS Volume: 32 Issue: 5 Pages: 456-468 Published: SEP 2017 
19. The potential of 3-dimensional construct engineered from poly(lactic-co-glycolic acid)/fibrin hybrid scaffold seeded with bone marrow mesenchymal stem Times Cited: 19 cells for in vitro cartilage tissue engineering

By: Rahman, Rozlin Abdul; Sukri, Norhamiza Mohamad; Nazir, Noorhidayah Md; et al.

TISSUE \& CELL Volume: 47 Issue: 4 Pages: 420-430 Published: AUG 2015

20. Tissue Engineering and Regenerative Medicine: Past, Present, and Future

Times Cited: 48

By: Salgado, Antonio J.; Oliveira, Joaquim M.; Martins, Albino; et al.

TISSUE ENGINEERING OF THE PERIPHERAL NERVE: STEM CELLS AND REGENERATION PROMOTING FACTORS Book Series: International Review of Neurobiology Volume: 108 Pages: 1-33 Published: 2013

21. Effect of in vitro culture on a chondrocyte-fibrin glue hydrogel for cartilage repair

Times Cited: 28

By: Scotti, Celeste; Mangiavini, Laura; Boschetti, Federica; et al.

KNEE SURGERY SPORTS TRAUMATOLOGY ARTHROSCOPY Volume: 18 Issue: 10 Pages: 1400-1406 Published: OCT 2010

22. Fibrin and poly (lactic-co-glycolic acid) hybrid scaffold promotes early chondrogenesis of articular chondrocytes: an in vitro study. By: Sha'ban, Munirah; Kim, Soon Hee; Idrus, Ruszymah Bh; et al.

Journal of orthopaedic surgery and research Volume: 3 Pages: 17 Published: 2008 Apr 25

23. Fibrin Sealant: Past, Present, and Future: A Brief Review

By: Spotnitz, William D.

WORLD JOURNAL OF SURGERY Volume: 34 Issue: 4 Pages: 632-634 Published:APR 2010

24. Engineering Cell Attachments to Scaffolds in Cartilage Tissue Engineering

Times Cited: 38

By: Steward, Andrew J.; Liu, Yongxing; Wagner, Diane R.

JOM Volume: 63 Issue: 4 Pages: 74-82 Published: APR 2011

25. Monomeric, porous type II collagen scaffolds promote chondrogenic differentiation of human bone marrow mesenchymal stem cells in vitro

Times Cited: 21

By: Tamaddon, M.; Burrows, M.; Ferreira, S. A.; et al.

SCIENTIFIC REPORTS Volume: 7 Article Number: 43519 Published: MAR 32017

26. Atelocollagen-associated autologous chondrocyte implantation for the repair of chondral defects of the knee: a prospective multicenter clinical trial in Japan

By: Tohyama, H.; Yasuda, K.; Minami, A.; et al.

JOURNAL OF ORTHOPAEDIC SCIENCE Volume: 14 Issue: 5 Pages: 579-588 Published: SEP 2009

27. Cartilage Tissue Engineering With Demineralized Bone Matrix Gelatin and Fibrin Glue Hybrid Scaffold: An In Vitro Study

By: Wang, Zheng-Hui; He, Xi-Jing; Yang, Zhuang-Qun; et al.

ARTIFICIAL ORGANS Volume: 34 Issue: 2 Pages: 161-166 Published: FEB 2010

28. Mechanisms of fibrin polymerization and clinical implications

Times Cited: 209

By: Weisel, John W.; Litvinov, Rustem I.

BLOOD Volume: 121 Issue: 10 Pages: 1712-1719 Published: MAR 72013

29. In vitro degradation of three-dimensional porous poly(D,L-lactide-co-glycolide) scaffolds for tissue engineering By: Wu, LB; Ding, JD

BIOMATERIALS Volume: 25 Issue: 27 Pages: 5821-5830 Published: DEC 2004

30. Reduction of inflammatory reaction of poly(D,L-lactic-Co-glycolic acid) using demineralized bone particles By: Yoon, Sun Jung; Kim, Soon Hee; Ha, Hyun Jung; et al. TISSUE ENGINEERING PART A Volume: 14 Issue: 4 Pages:539-547 Published:APR 2008

\section{Showing $\mathbf{3 0}$ of $30 \quad$ View All in Cited References page}

